УДК 346.34

DOI https: / / doi.org/10.32837/yuv.v0i4.978

\author{
С. Подоляк, \\ кандидат юридичних наук, \\ доцент кафедри господарського та адміністративного права \\ факультету соціології та права \\ Національного технічного університету України \\ «Київський політехнічний інститут імені Ігоря Сікорського»
}

\title{
ГОСПОДАРСЬКИЙ ДОГОВІР ПРО НАДАННЯ МАРКЕТИНГОВИХ ПОСЛУГ В УКРАЇНІ
}

Перехід України до ринкової економіки в умовах поглиблення конкуренціï вимагає у господарюючих суб'єктів професійного ставлення до споживчого попиту. Саме тому проведення маркетингового аналізу в його найефективніших формах в підприємницький діяльності стало об'єктивною необхідністю. Термінологія господарського договору про надання маркетингових послуг широко використовується в літературі, між тим його правове визначення залишається предметом дискусій. Маркетингові послуги та господарсько-договірні зв'язки між господарюючими суб'єктами, пов'язані 3 наданням маркетингових послуг, наполегливо входять в цивільний оборот і вимагають свого регулювання. Для сприяння підвищенню рівня маркетингових послуг в Україні та захисту суб'єктів ринку від некваліфікованого маркетингового обслуговування Українською Асоціацією Маркетингу (УАМ) на основі чинних міжнародних стандартів розроблено стандарт якості маркетингових досліджень УАМ 91.12.0-2108654001-2002 [1].

Метою статті є визначення правової природи господарського договору про надання маркетингових послуг, його особливостей та різновидів як однієї 3 ключових для розвитку ринкових відносин конструкцій, проведення аналізу чинного законодавства України в сфері надання послуг і формулювання пропозицій щодо його удосконалення.

Господарсько-договірні відносини та їх правове вираження - господар- ський договір є організаційним елементом економіки кожної країни. У правознавстві України категорія господарського договору залишається спірною. У ГК України визначення господарського договору відсутне, як і нема одностайності у визначенні цього поняття в літературі 3 господарського права, виданій в Україні за останні роки [4, с. 37]. При цьому термін (категорія) «господарський договір» використовується в таких значеннях: як угода (правочин), що породжує права та обов'язки учасників господарських відносин; як зобов'язання сторін (учасників господарських відносин), що грунтуються на укладеній ними угоді; як правовий документ, в якому фіксується факт угоди та зміст зобов'язання сторін.

О. А. Беляневич зазначає, що як соціально-правова категорія господарський договір має особливі ознаки [5, c. 456-457]:

1) сфера господарювання, як особлива сфера суспільних відносин, особлива цільова спрямованість господарських договорів виявляється в обслуговуванні безпосередньої господарської діяльності (як основної, так і допоміжної) та організації такої діяльності;

2) сторони зобов'язання - які є суб'єктами господарювання або іншими учасниками відносин у сфері господарювання;

3) юридичний об'єкт - певні дії господарського чи управлінського харак- 




теру (зокрема, виконання робіт, передача майна, сплата грошей, надання інформації тощо)

I лише за наявності зазначених ознак відносини, що склалися між сторонами внаслідок угоди, визначаються як господарсько-договірні $з$ поширенням на них норм спеціального законодавства, що регулює окремі види господарських договорів, порядок ї укладання та виконання, зміст, застосування різних видів господарсько-правової відповідальності за неналежне виконання.

Вчена А. Г. Бобкова з цього приводу вважає, що недостатність та нечіткість господарського законодавства, наявність проблем у правозастосуванні напряму пов'язані із невизначеністю правової природи господарського договору $[7$, с. 3$]$.

Як правило, дослідження господарського договору здійснюється 3 використанням традиційного для юриспруденції методологічного інструментарію. Ми використовуємо міждисциплінарний підхід, сформований в рамках синергетики. Синергетика надає нам можливість розглянути господарський договір як відкриту самоорганізуючу соціально-правову господарську систему, яка може бути описана на вербальному рівні із використанням для дослідження методу системного аналізу.

Сутність системи права полягає в тому, що іï складові частини - галузі права - не тільки відмежовуються одна від одної, але й нерозривно пов'язані між собою, відображаючи властивість єдиної системи як цілого. Це стосується й співвідношення цивільного та господарського права [8, с. 31].

Господарське договірне право одночасно виступає складовою господарського права (його інститутом) i системою нижчого рівня в системі права в цілому [6, с. 81]. Під цим кутом зору підсистема «господарський договір» $€$ елементом господарського договірного права. Враховуючи концепцію загального підходу системного методу пізнання, що невід’ємною властивістю будь-якої системи є ї відносність, тобто що кожна система може розглядатися як елемент іншої, більш широкої системи - системи більш широкого порядку - можна і господарський договір розглянути як систему.

3 одного боку, господарське договірне право можна представити як сукупність норм та відносин, які створені самими суб'єктами цих відносин у порядку самоорганізації та саморегулювання, а господарський договір - це інструмент господарського договірного права, а з іншого, - держава, як гарант цивільного суспільства, за допомогою системи норм виступає регулятором господарсько-договірних відносин захищає та реалізує ці відносини за допомогою державних засобів примусу.

Розглядаючи загальне поняття господарського договору, виходячи із синергетичного визначення системи, що система - це сукупність об'єктів та процесів («компонентів»), які мають поміж собою взаємозв'язок та взаємодію й створюють єдине ціле 3 властивостями, яких не має жоден із компонентів окремо [9, с. 22] можна зробити висновок, що господарський договір, з одного боку, виконує функцію юридичного факту, з яким пов'язується виникнення у конкретних учасників господарських відносин прав та обов'язків (індивідуалізованих правил поведінки), з іншого боку, як зобов'язання, виступає ключовим елементом стадії реалізації норм, в якому поєднуються використання дозволянь, дотримання заборон, виконання зобов'язань, і який спрямований на досягнення соціально значущих цілей та задоволення певних інтересів учасників господарських відносин та інтересів суспільства в цілому [6, с. 73]. Саме така багатофункціональність господарського договору і надає нам можливість розглянути його як соціально-правову господарську систему, яка складається із компонентів - елементів системи, поєднаних між собою функціональними правовими зв'язками, й також має 
універсальну конструкцію, яка надає можливість виокремити такі основні елементи соціально-правової системи «господарський договір»: контрагенти; істотні умови договору; угода сторін; зобов'язальні правовідносини; правова мета договору (підтримуючи концепцію, що господарський договір як угода має визначену правову та економічну мету, в дослідженні розглядався тільки правовий аспект).

При цьому конструкція господарського договору як засобу організації господарсько-договірних відносин базується на законодавчих імперативних нормах, які створюють зовнішнє правове поле і виконують функції контролю правомірності цих відносин.

Узагальнюючи все зазначене вище, загальну нормативно-правову модель господарського договору можна відобразити як модель правовідносин, які виникають на основі господарського договору, а саме сукупності умов господарського договору щодо розподілених між учасниками договірного процесу на підставі їх угоди прав та обов'язків, реалізація яких спрямовується на досягнення правової мети договору.

Аналізуючи зазначену модель господарського договору як соціально-правову господарську систему, можна стверджувати, що вона визначає його структуру та кінцеву мету. Системність господарського договору виявляється не тільки в тому, що він складається із функціональних частин - юридичних компонентів, пов'язаних поміж собою функціональними зв'язками (формами реалізації права), а ще й у тому, що ця система існує не в замкнутому просторі, а в зовнішньому правовому полі і в зовнішньому середовищі. Стабільність та сталість системи залежать від реалізації процесу самоорганізації - наявності механізмів саморегуляції. Можна відзначити, що соціально-правовій системі «господарський договір» притаманні два види механізмів саморегуляціі:

- договірна саморегуляція від’ємні зворотні зв'язки, котрі за допо- могою особливих засобів впливу (санкцій) урівноважують систему;

- процесуально-договірна саморегуляція - додатні зворотні зв'язки (мирові угоди), котрі не стримують нерівновагу системи, а переводять їі на інший рівень рівноваги за допомогою зміни прав та обов'язків.

За такого підходу правова сутність господарського договору полягає в організації (у тому числі самоорганізаціi) господарсько-договірних відносин, спрямованих на досягнення правової мети, при цьому норми права виконують роль нормативно-правового регулятора цих відносин.

Спробуємо використати для дослідження розроблене нами авторське визначення господарського договору як соціально-правової господарської системи, заснованої на угоді сторін, що слугує юридичною (правовою) підставою виникнення зобов'язальних правовідносин, за якими визнається юридичний (правовий) характер, та спрямованої на досягнення правової мети [10, с.19-21].

Розглянемо конструкцію господарського договору про надання маркетингових послуг як соціально-правову господарську систему:

-контрагенти (суб'єкти господарювання): замовник і виконавець-маркетолог;

-істотні умови договору (предмет договору): маркетингові послуги для підвищення ефективності власного виробництва та оптимізації бізнес-процесів, які визначають предмет договору: розміщення в місцях продажу, вивчення, дослідження та аналіз споживчого ринку (окремих його елементів, зокрема учасників, товарів, попиту, пропозиції тощо) та/або сформувати пропозиції щодо способів досягнення визначеної замовником або іншою особою мети на ринку (формування або підвищення попиту, стимулювання збуту тощо); ціна; строк дії договору (ч.3 ст.180 ГК України) [2];

-угода сторін договору: виконавець-маркетолог зобов'язується вико- 


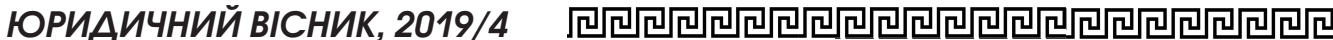

нати завдання замовника, а замовник зобов'язується оплатити виконавцеві надання визначених договором послуг;

-правова мета договору: надання звіту про проведення маркетингових досліджень з їх результатами та рекомендаціями замовнику;

-економічна мета договору: отримання ефекту результативності маркетингових послуг, який не виникає в момент ї завершення, наслідком чого може бути не гарантованість результату послуги тобто слідування сформульованим рекомендаціям та пропозиціям, в тому числі, втіленим у маркетингову програму або стратегію, не гарантує одержання запланованого результату [11, с.157]. На наш погляд, це вимагає конкретної правової регламентації результату маркетингових послуг, гарантій, що бере на себе виконавець, по досягненню такого результату.

Вищевикладене доводить, що правова сутність господарського договору про надання маркетингових послуг повністю співпадає із запропонованим нами загальним визначення господарського договору як соціально-правової господарської системи, заснованої на угоді сторін, що слугує юридичною (правовою) підставою виникнення зобов'язальних правовідносин, за якими визнається юридичний (правовий) характер, та спрямованої на досягнення правової та економічної мети.

Враховуючи різноманітність цільової спрямованості маркетингових послуг, та характеру дій, що становлять їх зміст, можна зробити умовну диференціацію господарських договорів про надання маркетингових послуг в залежності від обраного терміну дії договорів в частині істотних умов договору: 1) при довгостроковій співпраці предмет договору визначає загальний перелік послуг та загальні умови виконання, а в додаткових угодах визначають місце проведення дослідження, строки виконання тощо; 2) при разовій співпраці предмет договору визначає конкретні завдання, строк виконання, ціну, місце проведення.

Широко розповсюдженим прикладом короткострокового договору є господар- ський договір про надання маркетингових послуг мерчандайзингу - вдалого розміщення товарів у торговому залі, оригінального оформлення прилавків і вітрин, організація презентацій із роздаванням сувенірів, наданням знижок та пільг тощо.

Українське законодавство досі не передбачило механізмів правового регулювання господарських договорів про надання маркетингових послуг, які мають свою специфіку та особливості. Тому стає очевидною необхідність перегляду наукових підходів до господарсько-договірних відносин в цій сфері задля підвищення їх якості та ефективності. Господарський кодекс України в ст.6 визначає серед загальних принципів господарювання вільний рух капіталів, товарів та послуг на території України, а в ст.259 ч.1 [2] прямо відносить надання послуг до різновидів господарської діяльності, при цьому зазначає, що окремий вид діяльності може складатися як $з$ єдиного простого процесу так і охоплювати ряд процесів, кожний 3 яких входить до відповідної категорії класифікації. 3 такої точки зору можна вважати, що маркетингові послуги (маркетингові дослідження) за правовим режимом займають проміжне становище між господарським договором про надання послуг і господарським договором про науково-дослідні дослідження [11, с.157]. Ст.180 ГК України не надає конкретного визначення предмету договору (ч.3), між тим узагальненою назвою «умови про предмет у господарському договорі» охоплює найменування (номенклатуру, асортимент) та кількість продукції (робіт, послуг), а також вимоги до їх якості [2].

У той же час ст.901 Цивільного кодексу України [3] нормативно закріплює загальне визначення договору про надання послуг. Таким чином ГК України визначає надання послуг господарською діяльністю, а ЦК України - цивільно-правовою категорією.

Таким чином, можна стверджувати, що договори про маркетингову діяльність при тому, що займають важливе місце в класифікації договорів про надання 
послуг, досі не знайшли гідного місця ні в системі господарського, ні в системі цивільного права.

Підсумовуючи викладене, можна стверджувати, що дослідження правової природи господарського договору про надання маркетингових послуг як соціально-правової господарської системи із використанням синергетичного методу довело достовірність кінцевого результату та ефективність вибору методу дослідження. Враховуючи, що маркетингові послуги $€$ способом задоволення потреб господарської діяльності, а замовником та виконавцем $€$ господарюючи суб'єкти ми вважаємо доцільним закріплення в ГК України господарського договору про надання маркетингових послуг із виокремленням повного переліку конкретних умов договору й конкретної правової регламентації результату маркетингових послуг, а саме, гарантій, що бере на себе виконавець по досягненню такого результату.

У статті проводиться дослідження ефективності правового регулювання господарського договору про надання маркетингових послуг в законодавстві України в умовах ринкової економіки. Здійснюеться аналіз сучасних підходів до загального визначення поняття господарського договору відомих українських вчених-правознавиів. За допомогою синергетичного методу досліджено господарський договір як відкриту самоорганізуючу соиіально-правову систему. Розглянуто вербальну нормативно-правову модель системи господарський договір на базі якої розкрито його юридичну природу $i$ сформульовано авторське визначення господарського договору як соціально-правової господарської системи, заснованої на угоді сторін, що слугуе юридичною (правовою) підставою виникнення зобов'язальних правовідносин, за якими визнається юридичний (правовий) характер, та спрямованої на досягнення правової мети. Зроблено аналіз господарського договору про надання маркетингових послуг, розглянуто його конструкцію як соціально-правової господарської системи, виокремлені особливості окремих його структурних елементів. Доведено, що правова сутність господарського договору про надання маркетингових послуг повністю співпадає із запропонованим нами визначенням господарського договору як соціально-правової господарської системи.

Важливою відмінністю господарського договору про надання маркетингових послуг нами визначено особливе значення економічної мети договору отримання ефекту результативності маркетингових послуг, який не виникає в момент їх завершення, наслібком чого може бути не гарантованість результату послуги тобто слідування сформульованим рекомендаціям та пропозиціям, в тому числі, втіленим у маркетингову програму або стратегію, не гарантує одержання запланованого результату.

Проведений аналіз чинного законодавства України в сфері надання послуг довів, що українське законодавство досі не передбачило механізмів правового регулювання господарських договорів про надання маркетингових послуг, які мають свою специфіку та особливості. Запропоновано основні напрямки удосконалення господарського законодавства України в изьому пuтаннi.

Ключові слова: господарський договір, надання маркетингових послуг, замовник, виконавець

\section{Podolyak S. ECONOMIC CONTRACT FOR MARKETING SERVICES IN UKRAINE}

In the article the effectiveness of legal regulation of economic contract for marketing services in the legislation of Ukraine is examined. The analysis of modern approaches to the general definition of the concept of economic contract done by well-known Ukrainian legal scholars is carried out. The economic contract was examined using the synergistic method as the open self- 




organizing social-legal system. The verbal normative-legal model of the economic contract system is considered. It was the basis for revealing the legal nature of economic contract and for representing the author's definition of economic contract as a socio-legal economic system based on the agreement of parties, which serves as a legal ground for the origin of obligatory legal relations, and aimed to achieve legal goal. The analysis of the economic contract for marketing services is made, its construction is considered as a sociolegal economic system, and the features of its individual structural elements are highlighted. It is proved that the legal point of economic contract for marketing services completely fits with our proposed definition of the economic contract as a socio-legal economic system.

The important difference of economic contract for marketing services is the special significance of the economic purpose of the contract - obtaining the effective marketing services, which does not occur at the time of their completion. So it may result to the lack of guarantee of the service result. Following the formulated recommendations and proposals, including implementing in the marketing program or strategy, does not guarantee the intended result.

The conducted analysis of the current legislation of Ukraine in the sphere of services has shown that our legislation has not yet provided the mechanisms of legal regulation of economic contracts for marketing services, which have their specific features. The basic directions of improvement of the economic legislation of Ukraine in this matter are offered.

Key words: economic contract, rendering marketing services, client, executor.

\section{Література}

1. Українська Асоціація Маркетингу [Електронний ресурс]. - Режим доступу: http: / / uam.in.ua/ukr/about /

2. Господарський кодекс Украіни від 16 січня 2003 року № 436-IV [Електронний ресурс]. - Режим docmyny: https: / / zakon.rada.gov.ua/ laws / show /436-15/print

3. Цивільний кодекс Украінни від 16 січня 2003 року № 435-IV [Електронний ресурс/. - Режим docmyny: https://zakon.rada.gov.ua/ laws / show /435-15/paran161\#n161\&p=

4. Луиь В. В. Тенденціі розвитку договірного права в сучасних умовах / В. В. Луцьь // Еволюція циивільного законодавства : проблеми теорії і практики : матеріали Міжнародної наук.-практ. конф. (м. Харків, 29-30 квітня 2004 р.). К. : Академія правових наук України; НдІ приватного права і підприємництва; НДІ інтелектуальної власності; Національна юридична академія ім. Ярослава Мудрого, 2004. - C. 32-39.

5. Договірне право Украӥни. Загальна частина: навч. посібник / /Боднар Т. В., Дзера О. В., Кузнєиова Н. С. та ін.J ; за ред. О. В. Дзери. - К. : Юрінком Інтер, 2008. - 896 c.

6. Беляневич O. А. Господарське договірне право України (теоретичні аспекти) : монографія / Беляневич O. А. K. : Юрінком Інтер, 2006. - 592 с.

7. Бобкова А. Г. Про господарські договори в рекреаційній діяльності / А. Г. Бобкова / / Правничий часопис Донещького універсuтетy. - 2000. - № 1 (4). - C. 13-17.

8. Шахматов В. П. Учение о правових нормах (общетеоретический и цивилистический аспекты) : библиогр. пособие / Шахматов В. П. - Красноярск : Изд-во Красноярского ун-та, 1985. - 156 с.

9. Пугачева Е.Г. Самоорганизация социально-экономических систем : учеб. пособие / Е. Г. Пугачева, К. Н. Соловьенко. - Иркутск: Издательство БГУЭП, 2003. - 171 с.

10. Недійсний та неукладений господарський договір: правові підстави та наслідки. Монографія / Подоляк С.А. Київ; Видавництво Ліра-К, 2012. - 214 с.

11. Мірзоян А. А. Окремі проблеми правового регулювання маркетингових послуг / А. А. Мірзоян // Актуальні проблеми юридичної науки: Збірник тез Міжнародної наукової конференцї «Шості осінні юридичні читання» (м. Хмельницький, 26-27 жовтня 2007 року): У 3-х частинах. - Частина друга: Цивільне право. Сімейне право. Міжнародне приватне право. Комериійне право. Цивільний процес. Трудове право. Право соціального забезпечення. - Хмельницький: Видавництво Хмельницького університету управління та права, 2007. - C. 155-158. 